Г. О. Човпан, І. С. Човпан, Л. В. Батюк, В. Г. Кнігавко Харківський національний медичний університет

\title{
ЗАСОБИ ПОЛІПШЕННЯ РОБОТИ ЗІ СТУДЕНТАМИ 3 АНГЛІЙСЬКОЮ МОВОЮ НАВЧАННЯ У МЕДИЧНИХ ВУЗАХ УКРАЇНИ ЗАЛЕЖНО ВІД ВХІДНОГО РІВНЯ ЗНАНЬ ТА КРАЇНИ-ДОНОРА
}

\author{
G. O. Chovpan, I. S. Chovpan, L. V. Batyuk, V. G. Knigavko \\ Kharkiv National Medical University

\section{THE METHODS OF IMPROVING WORK WITH ENGLISH LANGUAGE STUDYING STUDENTS IN UKRAINIAN MEDICAL SCHOOLS DEPENDING ON THE INPUT KNOWLEDGE LEVEL AND DONOR COUNTRY}

\begin{abstract}
Мета дослідження - знайти шляхи вирішення основних проблем, з якими стикаються викладачі, що працюють зі студентами-іноземцями молодших курсів з англійською мовою навчання. Проаналізувати основні проблеми, які можуть впливати на результативність навчання студентів-іноземців з англійською мовою навчання.

Матеріали та методи дослідження. Дослідження базується на вивченні матеріалів, отриманих із відкритих джерел інформації та власного досвіду авторів. У статті наведені сучасні технології тестування іноземних студентів з англійською мовою навчання, впроваджені на кафедрі медичної та біологічної фізики і медичної інформатики. Запропонований рейтинговий спосіб визначення залишкових після школи знань з математики, фізики та рівень володіння англійською мовою.

Результати й обговорення. На кафедрі медичної та біологічної фізики і медичної інформатики впроваджене вхідне рейтингове тестування іноземних студентів 1 курсу з англійською мовою навчання. Після проведення тестування викладачеві на електронну пошту надсилаються висновки у вигляді таблиці з результатами кожного студента та загальним результатом групи і надаються рекомендації щодо складу та рівня групи, пропонуються рекомендації з проведення занять з урахуванням особливостей конкретних навчальних груп. Також у роботі проаналізований можливий склад академічних груп та запропоновані деякі рекомендації щодо поліпшення роботи з урахуванням усіх факторів, наприклад, з урахуванням країн, із яких прибули студенти.

Висновки. Запропонований метод дозволяє викладачеві успішніше будувати освітній процес, що, в кінцевому підсумку, позитивно позначається на загальному засвоєнні курсу. У подальшому планується поширити тестування на студентів-іноземців із російською мовою навчання, запровадивши вхідне тестування російською мовою, що також може допомогти у вдосконаленні якості медичної освіти.
\end{abstract}

Ключові слова: тестуюча система; вхідний рівень знань; медичні вузи.

The aim of the study - to find solutions of the main problems faced by teachers working with students of younger courses with English language learning. We analyzed the main problems that could affect the effectiveness of the training of foreign students with English language learning.

Materials and Methods. The study is based on the investigation of the materials obtained from public sources and on the personal experience of the authors. The article presents the modern technologies of testing of foreign students with English language studying, implemented at the Department of Medical and Biological Physics and Medical Informatics. We proposed rating method of determination the residual after-school knowledge in Mathematics, Physics and level of English proficiency.

Results and Discussion. At the Department of Medical and Biological Physics and Medical Informatics entered input rating test for foreign 1st year students with English language learning. After the testing the teacher will receive by e-mail the conclusion in the form of a table with the results of each student and the overall group result and provided recommendations on the composition and level of the group offered recommendations for holding classes with the features of specific educational groups. The work also examines the possible composition of academic groups and proposed some recommendations for improvement, taking into account all factors, such as the countries from which students had arrived.

Conclusions. The proposed method allows the teachers to build a more successful educational process, which ultimately has a positive effect on the overall absorption rate. In the future we plan to extend testing of foreign students with Russian language of instruction, introducing entrance test in Russian that can also help in improving the quality of medical education.

Key words: testing system; input level of knowledge; medical schools.

(c) Г. О. Човпан, I. С. Човпан, Л. В. Батюк, В. Г. Кнігавко 
Вступ. Поліпшення якості навчання іноземних студентів - одне з пріоритетних питань серед педагогів медичних вузів. Це пов'язано як з давніми традиціями навчання іноземних студентів в українських медичних вузах, так і з загальносвітовою тенденцією до збільшення академічної мобільності, та з конкурентоспроможністю і високою якістю освіти вузів. Вочевидь, що чим вище якість освіти, тим більше освітніх інвестицій буде як у конкретному вузі, так і в країні в цілому.

Мета дослідження - знайти шляхи вирішення основних проблем, з якими стикаються викладачі, що працюють зі студентами-іноземцями молодших курсів 3 англійською мовою навчання. Необхідно проаналізувати основні проблеми, які можуть впливати на результативність навчання студентівіноземців $з$ англійською мовою навчання, а також основні чинники, що впливають на якість їх освіти.

Матеріали та методи дослідження. Дослідження базується на вивченні матеріалів, отриманих із відкритих джерел інформації [1-10] та власного досвіду авторів. У статті наведені сучасні технології тестування іноземних студентів з англійською мовою навчання, впроваджені на кафедрі медичної та біологічної фізики і медичної інформатики. Запропонований рейтинговий спосіб визначення залишкових після школи знань з математики, фізики та рівень володіння англійською мовою.

Результати й обговорення. Підвищення якості освіти залежить від застосування програм навчання, скоригованих залежно від психічних, розумових, інтелектуальних, професійних схильностей і загальних здібностей особистості учня. Підвищенню якості освіти іноземців має бути приділено особливо пильну увагу з точки зору методики, дидактики, психології навчання. Проаналізуємо труднощі, з якими стикаються іноземні студенти в українських вузах.

Акліматизація й адаптація. Під академічною адаптацією ми розуміємо адаптацію до нових умов і правил навчання, відмінних від правил, прийнятих у країні-донорі студента. Так само потрібно відзначити суто фізичну адаптацію, викликану відмінностями у кліматичних, часових поясах, іншим типом і навіть якістю їжі і води, які можуть відрізнятися від звичних у їх культурі й кліматі.

Культурні, релігійні відмінності. Культура вербальної і невербальної поведінки студентів нашої країни може разюче відрізнятися від звичок і особливостей студентів-іноземців, які часто навчаються у полінаціональних групах, де кожній окремій етнічній одиниці можуть відповідати свої культурні звичаї і норми, у тому числі й у культурі навчання.

Низький рівень залишкових шкільних знань з фізики, математики, а також і з інших предметів.

Низький рівень знання украӥнської або російської мови як мови спілкування в регіоні, де навчається студент, який дозволяв би йому легко адаптуватися в побутових питаннях.

У зв'язку з наведеним необхідні нові способи оцінки ефективності процесу навчання на основі рівня вхідних знань [6-8].

Передумовами до способу, що пропонується, є, по-перше, наявність соціокультурного рівня, рівня розмовної та професійної англійської мови викладацького складу, розуміння етнічного складу групи в цілому; по-друге, рівень мови студентів. Якщо рівень групи з англійської мови середній або нижче середнього, бути готовим перефразувати питання зі спрощеним, де можливо, формулюванням. Намагатися на час адаптації висловлюватися більш простими фразами, вміти пояснити зміст складного речення; по-третє, орієнтація на країну-донора та іiї культурно-освітні традиції.

Отже, який же може бути склад груп студентів-іноземців?

1. Англомовні групи з неангломовних країн.

Арабські студенти. Рівень англійської може сильно варіювати. Від низького, із складністю розуміє викладача, говорить повільно, насилу підбирає слова, до вище середнього, якщо це студент з інтелігентної родини, закінчив відмінну школу у себе в країні. Країни - Ліван, Сирія, Ірак, Палестина, Ізраїль, Єгипет, Ємен, Мальдіви та ін.

Особливості шкільної освіти і культурні традиції досить живою та доступною мовою викладено в циклі статей [4]. Особливості в навчанні. Культурні норми, прийняті в арабських країнах, помітно відрізняються від норм, прийнятих в Україні. Правила етикету в Україні близькі до загальноєвропейських, в той час як в арабських студентів свої норми, часто не завжди зрозумілі викладачу України. Наприклад, у кодекс ввічливості в арабських країнах входять обійми та поцілунки, в тому числі з представниками своєї статі при зустрічі. На практиці це означає, що під час адаптації студентів першого курсу заняття може перериватися незліченну кількість разів, якщо повз навчальної аудиторії буде проходити “земляк” або заходити студент, що спізнився. Викладачу не слід проявляти роздратування, слід пояснювати культурні відмінності у нашій країні вкупі з терплячим поясненням прийнятих у нас 
правил поведінки. Такі ж самі ситуації виникають тоді, коли арабському студенту здається, що “земляк” потребує допомоги. Певні труднощі можуть виникати у викладачів-жінок. В арабських країнах носіння хіджабів, тобто покрита голова, довга спідниця і відсутність декольте досі є абсолютною соціокультурною і навіть релігійною нормою. У нашій культурі жінка може одягатися значно вільніше, дотримуючись лише ділового стилю в одязі. Про ці відмінності варто пам’ятати, готуючись до занять. Вихід у медичному університеті досить простий - білий халат у жінки-викладача. Також досить неприємні проблеми може створювати дисципліна. Студенти з арабських країн у періоді адаптації потребують постійного нагадування про дисциплінарні норми, прийняті в українських вузах, вимогу приходити вчасно та у білому халаті, слухати викладача мовчки, не коментувати одночасно всім разом відповіді одного зі студентів.

- Студенти із Західної Європи, студенти іспаномовні.

Країни: Чорногорія, Перу. Рекомендації у цьому випадку досить загальні - орієнтація на вхідний рівень студента з базових предметів.

2. Англомовні студенти з англомовних країн.

- Індійські студенти.

- Африканські студенти з католицьких країн.

В обох випадках англійська мова є рідною або широко використовується як мова внутрішнього міжнаціонального спілкування. Відповідно, знання мови досить вільне, рівня advanced або upperintermediate. Часто спілкуються англійською мовою значно краще від викладача. Ускладнення взаємного розуміння частково пов' язано з акцентом країнидонора. Вхідний рівень досить високий, особливо стосується індійських студентів-заде і африканських студентів з Нігерії [4].

Що до культурно-освітніх особливостей індійських студентів, - до дисциплінарних норм відносяться ввічливо і виконують їх з повагою. До занять, як правило, готові, контакт із викладачем підтримують із задоволенням, активно відповідають на запитання і спокійно ставляться до виставлених оцінок, навіть якщо вони не є позитивні.

Африканські студенти. Типова ситуація для таких студентів - високий вхідний рівень підготовки, а також виняткова вмотивованість у навчанні $[5,6]$. У таких студентів завжди заповнений робочий зошит, завжди з собою лекційні матеріали, а також безліч питань перед заняттями. Єдиними двома особливостями можна вказати хіба що найвищу зацікавленість не тільки в знаннях, але й в оцінці, тобто студенти цієї групи, на відміну від індійських, можуть намагатися “випрошувати” оцінку, причому досить активно, віднімаючи у викладача час і сили. Рекомендацією може бути тверда впевненість у своїй компетентності, критерії оцінювання та підстави оцінки, на що потрібно спокійно, не дратуючись вказувати студенту. Друга особливість - рівень англійської мови. Як і в індійських країнах, у багатьох африканських країнах англійська мова вивчається як додаткова офіційна і використовується як мова міжнаціонального спілкування, тобто використовують ї̈ постійно і вільно, але, на жаль, вимова часто малозрозуміла.

Усі ці рекомендації пропонується надавати вчителю разом із результатами вхідних тестів з базових дисциплін, що допоможе, особливо молодим або новим викладачам, краще розуміти етнічний склад та культурно-освітні особливості студентів. У кінцевому підсумку це повинно істотно позначатися на вихідній результативності та загальній задоволеності роботою викладача.

Інтерпретація результату за формулою:

Result_of_student $=($ кількість правильних відповідей)/(кількість питань) * $100 \%$.

Автори пропонують наступне трактування результатів тесту кожного студента:

\begin{tabular}{|l|l|}
\hline \multicolumn{1}{|c|}{ Результат } & \multicolumn{1}{|c|}{ Інтерпретація результату } \\
\hline Вище $80 \%$ & Високий рівень \\
\hline $70-80 \%$ & Достатній рівень \\
\hline 50-69 \% & Задовільний рівень \\
\hline 49 \% і нижче & Низький рівень \\
\hline
\end{tabular}

Інтерпретація результатів групи в цілому проводиться в два етапи:

Крок 1. Середній результат групи по кожному 3 предметів розраховується за формулою:

Result_of_group = (сума результатів студентів, виражена у відсотках)/(кількість студентів).

Крок 2. Створення діаграми за допомогою JavaScript відповідно до кількості студентів, які отримали той чи інший результат. Останнім етапом тестування є пересилання результату викладачеві на електронну пошту.

Результат виглядає так (рис. 1).

Як вже було зазначено, істотною перевагою програми є можливість вносити за бажанням викладача власні питання і (або варіювати їх кількість), а також припиняти або продовжувати тест на свій розсуд, наприклад, в разі нестачі часу. 
Group result table

\begin{tabular}{|c|c|c|c|c|c|c|c|c|}
\hline Group & Surname & Faculty & Country & Year of gratuating school & English level, by student's meaning & English result, \% & Math result, $\%$ & Physics level, \% \\
\hline $9-21$ & Some_Name_and_surname & Dentist & Andorra & 2015 & Beginner & 25 & 33,3 & 36,4 \\
\hline $9-21$ & Igor_Chovpan & Dentist & Andorra & 2015 & Beginner & 25 & 66,7 & 72,7 \\
\hline & Average group level: & & & & & 25 & 50 & 54,5 \\
\hline
\end{tabular}

is $;$
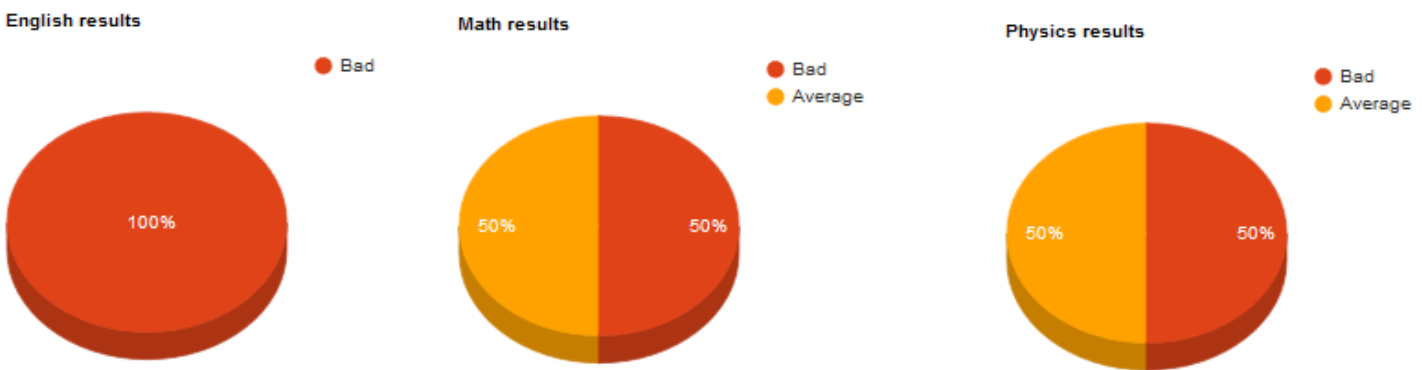

Рис. 1. Зразок результату, надісланий викладачеві на електронну пошту, скріншот екрана.

Дидактичні рекомендації у зв'язку з проведеним тестом

1. Орієнтація на мотивованого (-их) студента (-ів) групи.

У кожній групі є сильні і мотивовані один-два студенти, які завжди приходять підготовленими, із заповненим робочим зошитом, задають питання перед заняттям, із високим вхідним рівнем. Орієнтуватися на них, частіше ставити питання.

2. У групі з низьким рівнем залишкових знань давати можливість відповідати 3 лекційним зошитом або зошитом на друкованій основі на конкретно поставлені запитання. Можливі додаткові консультації зі студентами з питань базової математики і фізики.

3. Бути готовим перефразувати питання зі спрощеним, де це можливо, формулюванням. Намагатися на час адаптації висловлюватися більш простими фразами, вміти пояснити зміст складного речення. Викладачам постійно підвищувати рівень знань англійської мови, володіти синонімічними виразами, розмовною мовою і т. п.

4. Орієнтація на країну-донора та її культурноосвітні традиції.

Зовнішній вигляд викладача, ставлення до нього істотно залежить від країни-донора.

5. Перевірка лекційних зошитів. Чинить додатковий дисциплінуючий, виховний вплив, впливає на увагу і поведінку студентів під час лекцій.

У наступному році авторами планується поширити тестування на студентів-іноземців із російською мовою навчання, запровадивши вхідне тестування російською мовою, що також може допомогти у вдосконаленні якості медичної освіти.
Висновки. У роботі проаналізовані основні проблеми, з якими стикаються викладачі, що працюють з іноземцями молодших курсів 3 англійською мовою навчання. Для покращення роботи був запропонований спосіб визначення залишкових після школи знань $з$ математики, фізики та рівень володіння англійською мовою, а також надані рекомендації з проведення занять з урахуванням особливостей конкретних навчальних груп. Також у роботі проаналізований можливий склад академічних груп та запропоновані деякі рекомендації щодо поліпшення роботи з урахуванням усіх факторів, наприклад, з урахуванням країн, з яких прибули студенти. Авторами запропонована система тестування, яке розраховане на дві академічні години. Питання (англійською мовою) встановлені в тестуючу програму і відповідають програмі навчання в середній школі за курсом фізики і базової математики, питання з англійської мови не передбачають перевірку граматики, але розраховані на перевірку розуміння англійської мови, сенсу написаного тексту і базової лексики. Істотною перевагою програми є можливість додавати і скорочувати кількість питань у тесті, в разі, наприклад, браку часу, а також змінювати самі питання. Початок і закінчення тестування задаються самим викладачем. Після закінчення тестів система аналізує результати і відправляє їх на електронну пошту викладачеві.

Перспективи подальших досліджень. У подальшому планується поширити тестування на студентів-іноземців із російською мовою навчання, запровадивши вхідне тестування російською мовою, що також може допомогти у вдосконаленні якості медичної освіти. 


\section{Список літератури}

1. Клычева С. А. Адаптация иностранного студента к обучению в университете [Электронный ресурс] / С. А. Клычева. - 2013. - Режим доступа к ресурсу : http:// conf.grsu.by/alternant/2013/04/09/836/.

2. Брагин Ш. Б. Из опыта преподавания медицинской биологии на английском языке [Электронный ресурс] / Ш. Б. Брагин, Д. С. Зайка. - 2013. - Режим доступа к ресурсу : http://repo.knmu.edu.ua/ bitstream/123456789/735/1/689_online_konf.pdf.

3. Роль кураторской и психологической помощи в адаптации англоязычных студентов к обучению в вузе [Электронный ресурс] / Д. В. Кацапов, А. О. Сыровая, Л. Г. Шаповал, Е. Р. Грабовецкая. - 2013. Режим доступа к ресурсу : http://repo.knmu.edu.ua/ bitstream/123456789/735/1/689_online_konf.pdf.

4. Если ваш студент-иностранец [Электронный ресурс]. - 2005. - Режим доступа к ресурсу : http://www. tstu.ru/book/elib/pdf/2005/popovain.pdf.

5. Жбора И. В. Тестирование как метод контроля знаний студентов по химии в вузах I-II уровней аккредитации / И. В. Жбора, И. П. Стерчо, С. С. Милевич // Молодой ученый. - 2016. - № 3. - С. 818-821.

\section{References}

1. Klyicheva, S. (2013). Adaptatsiya inostrannogo studenta k obucheniyu v universitete [Adaptation of a foreign student to studying in the university] [Electronic resource]. -Available at: http://conf.grsu.by/alternant/2013/04/09/836/ [in Russian].

2. Bragin, Sh.B. (2013). Iz opyta prepodavaniya meditsinskoy biologii na angliyskom yazyike [From the experience of teaching of Medical Biology in English] [Electronic resource]. - Available at: http://repo.knmu.edu. ua/bitstream/123456789/735/1/689_online_konf.pdf [in Russian].

3. Katsapov, D.V. (2013). Rol kuratorskoy i psihologicheskoy pomoshchi $\mathrm{v}$ adaptatsyi angloyazyichnykh studentov k obucheniyu v vuze [The role of curatorial and psychological aid in adaptation of English speaking students in the university] [Electronic resource]. - Available at: http:// repo.knmu.edu.ua/bitstream/123456789/735/1/689_online_ konf.pdf [in Russian].

4. (2005). Esli vash student-inostranets [If your student is a foreigner] [Electronic resource]. - Available at: http:// www.tstu.ru/book/elib/pdf/2005/popovain.pdf [in Russian].

5. Zhbora, I.V., Stercho, I.P., \& Milevich, S.S. (2016). Testirovanie kak metod kontrolya znaniy studentov po khimii v vuzah I-II urovney akkreditatsii [Testing as a method of knowledge control of students in Chemistry in the universities of I-II accreditation levels. Molodoy uchenyi - Young Scientist, 3, 818-828 [in Russian].
6. Аванесов В. С. Основы научной организации педагогического контроля в высшей школе / В. С. Аванесов. - М. : МИСиС, 1989. - 176 с.

7. Семинский И. Ж. Особенности использования тестирования для оценки качества знаний студентов в медицинском вузе / И. Ж. Семинский, Л. О. Гуцол, Е. В. Гузовская // Сибирский медицинский журнал. 2010. - № 98.

8. Мовчан Н. И. Стандартизация образовательного процесса посредством внедрения тестовых технологий / Н. И. Мовчан, Р. Ф. Бакеева, В. Ф. Сопин // Вестник Казанского технологического университета. - 2004. № 2.

9. Альтшулер О. Г. Сравнение субъективных и объективных оценок компьютерного тестирования / О. Г. Альтшулер, О. М. Колесников, Т. Ю. Павлова // Вестник Кемеровского государственного университета. - 2012. - № 1.

10. Тесты по английскому [Электронный ресурс]. Режим доступа к ресурсу : http://testuz.ru/.

6. Avanesov, V.S. (1989). Osnovy nauchnoy organizatsii pedagogicheskogo kontrolya $v$ vysshey shkole [Bases of scientific organization of pedagogical control in high school]. Moscow: MISiS [in Russian].

7. Seminskiy, I.Zh. (2010). Osobennosti ispolzovaniya testirovaniya dlya otsenki kachestva znaniy studentov $\mathrm{v}$ meditsinskom vuze [Peculiarities of usage of tests for evaluation of knowledge quality in students of medical university]. Sibirskiy meditsynskiy zhurnal - Siberian Medical Journal, 98 [in Russian].

8. Movchan, N.I. (2004). Standartizatsiya obrazovatelnogo protsessa posredstvom vnedreniya testovykh tekhnologiy [Standardization of educational process by implementation of test technologies]. Vestnik Kazanskogo tekhnologicheskogo universiteta - Journal of Kazan Technological University, 2 [in Russian].

9. Altshuler, O.G. (2012). Sravnenie subyektivnykh i obektivnykh otsenok kompyuternogo testirovaniya [Comparison of subjective and objective marks of computer testing]. Vestnik Kemerovskogo gosudarstvennogo universiteta - Journal of Kemerovo State University, 1 [in Russian].

10. Testy po angliyskomu [Tests in English] [Electronic resource]. - Available at: http://testuz.ru/ [in Russian].

Отримано 17.01.17 